Caroline Rizza, Paula Curvelo, Inês Crespo, Michel Chiaramello, Alessia Ghezzi, Ângela Guimarães Pereira:

\title{
Interrogating Privacy in the digital society: media narratives after $\mathbf{2}$ cases
}

\begin{abstract}
:
The introduction of information technology (IT) in the society and its pervasiveness in every aspect of citizens' daily life highlight societal stakes related to the goals regarding the uses IT, such as social networks. This paper examines two cases that lack a straightforward link with privacy as addressed and protected by existing law in Europe (EU) and the United-States (USA), but whose characteristics, we believe fall on other privacy function and properties. In Western societies, individuals rely on normative discourses, such as the legal one, in order to ensure protection. Hence, the paper argues that other functions of privacy need either further framing into legislation or they need to constitute in themselves normative commitments of an ethical nature for technology development and use. Some initiatives at the EU level recall such commitments, namely by developing a normative discourse based on ethics and human values. We argue that we need to interrogate society about those normative discourses because the values we once cherished in a non-digital society are seriously being questioned.
\end{abstract}

\section{Agenda:}

Models of Privacy and/in Legal Provisions

Beyond personal data: two tales in the news media $\quad 11$

Weinergate $\quad 12$

Puddick "Online Harrassment" 13

Discussion: privacy concerns in the two cases $\quad 14$

Making a case for privacy in the two cases 14

$\begin{array}{ll}\text { Technologies of privacy } & 15\end{array}$

Towards an ethics of social networks $\quad 15$

\section{Authors:}

Dr. Caroline Rizza

- European Commission, Joint Research Centre (JRC), Institute for the Protection and the Security of the Citizen (IPSC). Via Enrico Fermi 2749 - I-21027 Ispra (VA) - Italy.

疋 + 39 - 0332 - $789746, \square$ caroline.rizza@jrc.ec.europa.eu, 믈 http://ipsc.jrc.ec.europa.eu/

- Relevant publications:

- Rizza, C. (2012, forthcoming), "Digital competences", Encyclopedia of Quality of Life Research, Springer.

- Rizza, C. (2012, forthcoming), "Digital divide", Encyclopedia of Quality of Life Research, Springer.

- Rizza, C. \& Mahmoud, S. (2011). « Les potentialités du web 2.0 dans le domaine de l'apprentissage : simple effet de mode ou véritable enjeu pour l'éducation ? », in Apprentissage Ubiquitaire et Web 2.0 , Bonfils, P., Pieri, M. , \& Dumas P. (Ed.), Paris, L'Harmattan.

Paula Curvelo

- European Commission, JRC, IPSC. Via Enrico Fermi 2749 - I-21027 Ispra (VA) - Italy.

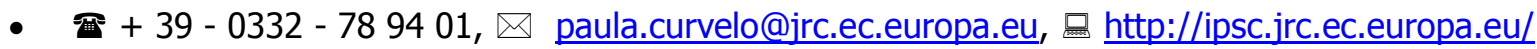


Inês Crespo

- European Commission, JRC, IPSC. Via Enrico Fermi 2749 - I-21027 Ispra (VA) - Italy.

- 急 + 39 - 0332 - 7891 55, $ه$ ines.crespo@jrc.ec.europa.eu, 므 http://ipsc.jrc.ec.europa.eu/

- Relevant publications:

- De Sousa Brilhante Pedrosa T., Orfao Crespo I., and Guimarães Pereira Â. (2009). Media Analysis: EMM Application to CPSI Framework. EUR 23778 EN. Luxembourg (Luxembourg): OPOCE; 2009. JRC50765

Michel Chiaramello

- European Commission, JRC, IPSC. Via Enrico Fermi 2749 - I-21027 Ispra (VA) - Italy.

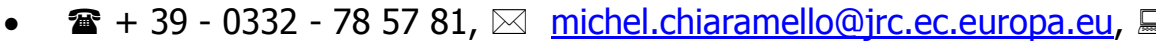

http://ipsc.jrc.ec.europa.eu/

Alessia Ghezzi

- European Commission, JRC, IPSC. Via Enrico Fermi 2749 - I-21027 Ispra (VA) - Italy.

- 面 + 39 - 0332 - 7892 44, $\bowtie$ alessia.ghezzi@jrc.ec.europa.eu, 모 http://ipsc.jrc.ec.europa.eu/

Dr. Ângela Guimarães Pereira

- European Commission, JRC, IPSC. Via Enrico Fermi 2749 - I-21027 Ispra (VA) - Italy.

面 + 39 - 0332 - 7853 40, $ه$ angela.pereira@jrc.ec.europa.eu, 몽 http://ipsc.jrc.ec.europa.eu/

- Relevant publications:

- Guimarães Pereira, Â. and Funtowicz, S. (2009). Science for Policy. Oxford: Oxford Univ. Press.

The content of this paper does not reflect the official opinion of the European Commission. Responsibility for the information and views expressed lies entirely with the authors. 
In the Western digital society, many initiatives to protect privacy are being set either through regulatory mechanisms, practice or just changes of "jargon" in order to align the legal discourse with other normative discourses. Concurrently, the news media often report cases where many functions, properties and dimensions of privacy are not being adequately resolved by current provisions in law; most importantly is that those would need thorough societal reflection before being transposed into the legal discourse. A myriad of authors (e.g. De Hert and Gutwirth, 2006; Poullet, 2010; Andrade, 2011) have devoted a great deal of attention to study current provisions of European Union (EU) law on privacy matters. We found through two recent cases of social media usage that many privacy functions and properties are neither contemplated in the law nor even articulated in the normative discourses that permeate society, namely those echoed by news media.

This paper first offers a brief review of models and foundations of privacy, followed by a description of legal provisions both in the EU and Unites States of America (USA); it then looks at the two cases that have inspired this work, the Weiner case in the USA (e.g. Klein, 2011; Pershing, 2011) and the Puddick case in the United Kingdom (UK) (e.g. Blake, 2011a; Davies, 2011). Albeit those are different stories about technology usage, they share that none of them has been framed in the media's narratives as a privacy case. For the former the media concentrated on IT operational aspects which compromised Mr. Weiner's public image whereas in the latter case, the news media mainly focused on the results of the court case arising from the use of social media by Mr. Puddick.

However, when looking at privacy foundations literature, we are surprised that many of these functions have been disregarded along the storyline of the cases and not even being alluded to by news media. Hence, in this paper we describe what the media discourses were for the two cases. We argue that those narratives are not contemplate issues of privacy. Moreover, we also suggest that the existing EU legislation could have been used to address the Puddick court case. Finally, we argue that, as in many other fields, a thorough discussion of values and ethics that we as humans want to preserve or develop within the technoscientific endeavour needs to be settled and the trinomial technology-law-ethics needs urgent articulation.

\section{Models of Privacy and/in Legal Provisions}

The concept of privacy constitutes a relatively new concept in the development of contemporary law (De Hert and Gutwirth, 2006) even if it has broad historical roots in philosophical, political, sociological and anthropological discussions (DeCew, 2008). Two important theories have been influencing the meaning and value of privacy within the western political tradition, which are considered to be the most authoritative by several authors (Pedersen 1999; Carew and Stapleton 2005; Joinson and Paine 2007; Margulis 2011).

The first one, developed by Westin (1967), defines privacy as "the claim of individuals, groups, or institutions to determine for themselves when, how, and to what extent information about them is communicated to others" (Idem). This conception focuses on informational privacy (a subset of social interaction) and includes "the voluntary and temporary withdrawal of a person from the general society through physical or psychological means" (Ib. idem). For Westin, the concept of privacy, i.e. the need for the 'opacity' of the individual, is not an end in itself, but a means to achieve the overall end of self-realisation. According to this conception, Westin postulates four functions and four states of privacy, as presented in Figure 1. 


\begin{tabular}{|c|c|c|c|}
\hline \multicolumn{4}{|c|}{$\begin{array}{c}\text { The four functions } \\
\text { of privacy }\end{array}$} \\
\hline $\begin{array}{l}\text { Personal } \\
\text { autonomy }\end{array}$ & $\begin{array}{l}\text { Emotional } \\
\text { release }\end{array}$ & $\begin{array}{l}\text { Self- } \\
\text { evaluation }\end{array}$ & $\begin{array}{c}\text { Limited \& } \\
\text { protected } \\
\text { communication }\end{array}$ \\
\hline $\begin{array}{l}\text { To avoid being } \\
\text { manipulated, } \\
\text { dominated or } \\
\text { exposed by } \\
\text { others }\end{array}$ & $\begin{array}{l}\text { To "let go" } \\
\text { emotions and } \\
\text { tensions } \\
\text { resulting from } \\
\text { social } \\
\text { demands }\end{array}$ & $\begin{array}{l}\text { To integrate } \\
\text { experience } \\
\text { into } \\
\text { meaningful } \\
\text { patterns and } \\
\text { exert } \\
\text { individuality } \\
\text { on events }\end{array}$ & $\begin{array}{l}\text { The former to } \\
\text { set } \\
\text { interpersonal } \\
\text { boundaries and } \\
\text { the latter to } \\
\text { share personal } \\
\text { information } \\
\text { with trusted } \\
\text { others }\end{array}$ \\
\hline
\end{tabular}

The four states of privacy

\begin{tabular}{|c|c|c|c|}
\hline & & & \\
\hline Solitude & Intimacy & Anonymity & Reserve \\
\hline $\begin{array}{l}\text { The state of } \\
\text { being free } \\
\text { from } \\
\text { observation } \\
\text { by others }\end{array}$ & $\begin{array}{l}\text { The } \\
\text { seclusion } \\
\text { required for } \\
\text { a close } \\
\text { association }\end{array}$ & $\begin{array}{l}\text { The condition } \\
\text { of being } \\
\text { unknown } \\
\text { and free from } \\
\text { identification }\end{array}$ & $\begin{array}{l}\text { The desire } \\
\text { to limit } \\
\text { disclosures } \\
\text { to others }\end{array}$ \\
\hline
\end{tabular}

Figure 1. Westin's conception of privacy (1967): the four functions and states of privacy

The second theory, developed by Altman (1975), defines privacy as "the selective control access to the self" $(1975$, p. 24). The social interactions, the social and physical environment and the cultural context are considered fundamental features to understand the different properties of privacy and the multiple behavioural mechanisms for its regulation. Carew and Stapleton (2005) show that in Altman's theory, privacy has five properties, among which the "units of privacy" referring to two levels of privacy can apply: individual or group (Figure 2).

The Five properties of Privacy

\begin{tabular}{|c|c|c|c|c|}
\hline $\begin{array}{l}\text { Units of } \\
\text { privacy }\end{array}$ & $\begin{array}{l}\text { Dialectic } \\
\text { nature }\end{array}$ & $\begin{array}{l}\text { Non- } \\
\text { monotonic } \\
\text { nature }\end{array}$ & $\begin{array}{c}\text { Boundary } \\
\text { control } \\
\text { process }\end{array}$ & $\begin{array}{c}\text { directional } \\
\text { process }\end{array}$ \\
\hline $\begin{array}{l}\text { - Person-to- } \\
\text { person } \\
\text { - Person-to- } \\
\text { group } \\
\text { - Group-to- } \\
\text { person } \\
\text { - Group-to- } \\
\text { group }\end{array}$ & $\begin{array}{l}\text { Force } \\
\text { drawing } \\
\text { individual } \\
\text { together } \\
\text { Vs. Force } \\
\text { pushing ther } \\
\text { apart }\end{array}$ & $\begin{array}{l}\text { Equilibrium } \\
\text { at a given } \\
\text { time } \\
\text { em }\end{array}$ & $\begin{array}{l}\text { Flexible } \\
\text { barrier } \\
\text { between } \\
\text { the self and } \\
\text { the non-self }\end{array}$ & $\begin{array}{l}\text { Control of: } \\
\text { - Inputs } \\
\text { from others } \\
\text { - \& Outputs } \\
\text { to others }\end{array}$ \\
\hline
\end{tabular}

Figure 2. Altman's conception of privacy (1975): the five properties of privacy

The main difference between these two theories results from the emphasis that Altman gives to social interaction, which leads to a more inclusive conception of privacy. Besides that, these two theories share several commonalities (see Margulis, 2011, p.15).

In the present paper, these theories serve the purpose of introducing the discussion around the dominant conception of privacy in a digital society and how this conception has been changing with the pervasiveness of information technology (IT) in the society, e.g. social networks. It is a truism that IT has been impacting citizens' daily life but the privacy meanings need to be interrogated. In particular, the means so far implemented to defend and protect what we could call an "ethical" conception of privacy. 
According to De Hert and Gutwirth (2006) the development of the democratic constitutional state has led to the invention of two complementary legal tools of power control: 1) the normative opacity tools that draw the limits of interference with individuals, and 2) the transparency tools that organize the channelling, control and restraint of power. For the authors, privacy is an example of an opacity tool, which sets normative limits to powers, while data protection can be mainly seen as a transparency tool, which regulates and channels necessary, reasonable and legitimate power.

Whilst data protection is a pragmatic concept in its nature and a means to protect individuals' privacy (De Hert and Gutwirth, 2006; Poullet, 2010) protecting the value and interest of privacy as it protects the value and interest of identity, security and freedom of information, among others (Andrade, 2011, p.98), it also constitutes a limited proxy to address other functions and properties of privacy. As we will see much of the current EU and USA legal discourses are based on data protection as a proxy for privacy protection.

In the remaining of this section we look at how models of privacy have been articulated in the legal systems of both EU and USA for online communications. The way legislation defines and protects privacy differs strongly among those regions, and in particular for the former there are great differences between the Member States (MSs). Referring to the theoretical models of privacy presented earlier, this distinction is easily understandable since the conception of privacy, as an "opacity tool", has been constructed in diverse social, physical and cultural contexts. Therefore, resulting differences of privacy conceptions have also influenced the "transparency tools" adopted, such as personal data protection legislation, implemented to protect privacy or other values.

In the USA, privacy is not explicitly protected by the Constitution or by one unique federal law but it is considered as a valued right (Strauss and Rogerson, 2002; KWR Gmbh, 2006). The Privacy Act (1974) regulates how the government can collect American citizens' personal data. At the level of the State, only California has enacted a set of laws protecting its residents' privacy such as the "California Online Privacy Protection Act" (2003) that requires the publication of a privacy policy by operators collecting personal data through Internet (KWR Gmbh , 2006). For the IT private sector, a few narrow industry-specific federal laws can be applied. Especially, the "Fair Information Principles" or "Practices" guide privacy policy for this sector. These principle cover five aspects: "notice", "choice", "access", "security" and "contact" (Strauss and Rogerson, 2002, pp. 177-178) - see Figure 3. Organizations are not required to observe these principles; nevertheless they are used as benchmarks for evaluating data collection and privacy protection since 1980.

\begin{tabular}{|c|c|}
\hline \multirow{2}{*}{$\begin{array}{l}\text { At the } \\
\text { Federal } \\
\text { Level }\end{array}$} & The Privacy Act (1974) \\
\hline & Sectorial approach (specific Laws) for the private sector \\
\hline \multirow{5}{*}{$\begin{array}{l}\text { The fair } \\
\text { Information } \\
\text { Principles } \\
\text { (or } \\
\text { Practices) } \\
\text { For the } \\
\text { Private sector } \\
\text { but has also } \\
\text { influenced } \\
\text { the Privacy } \\
\text { Act }\end{array}$} & $\begin{array}{l}\text { "Notice": "a data-collector clearly tells the subject exactly } \\
\text { what information is being collected, how it is collected, how } \\
\text { that information will be used, and with whom it will be } \\
\text { shared"; }\end{array}$ \\
\hline & $\begin{array}{l}\text { "Choice": "allows consumers to actually exercise control } \\
\text { over the use of their data" }\end{array}$ \\
\hline & $\begin{array}{l}\text { "Access": "allows individuals to easily review the } \\
\text { information that has been collected about them. (...) The } \\
\text { privacy policy should describe how an individual could } \\
\text { request a correction". }\end{array}$ \\
\hline & $\begin{array}{l}\text { "Security": "requires data collectors to protect their } \\
\text { gathered information, both during transmission and storage" }\end{array}$ \\
\hline & $\begin{array}{l}\text { "Contact": "fair information practices require that collectors } \\
\text { provide subjects with reliable "contact" information" }\end{array}$ \\
\hline $\begin{array}{l}\text { At the } \\
\text { States' level }\end{array}$ & $\begin{array}{l}\text { The California Online Privacy Act (2003) and others specific } \\
\text { laws - California is the only State having enacted such kind of } \\
\text { law. }\end{array}$ \\
\hline
\end{tabular}

Figure 3. Personal data protection in the United-States

In the EU, personal data protection is both regulated and institutionalized (Strauss and Rogerson, 2002). The regulation has been implemented since 1981 with the convention for the "Protection of individuals with regard to automatic processing of personal data" by the Council of Europe. A set of European Directives have followed as a way to respond to the progress in the technological field, and have been covering a set of principles, all presented in the Figure 4. These Directives respectively aim to provide a uniform level of 
data protection in the European Union and in particular of privacy, as well as to facilitate the free flow of personal data in Europe (Strauss and Rogerson, 2002; Kuczerawy, 2010; KWR Gmbh, 2006).

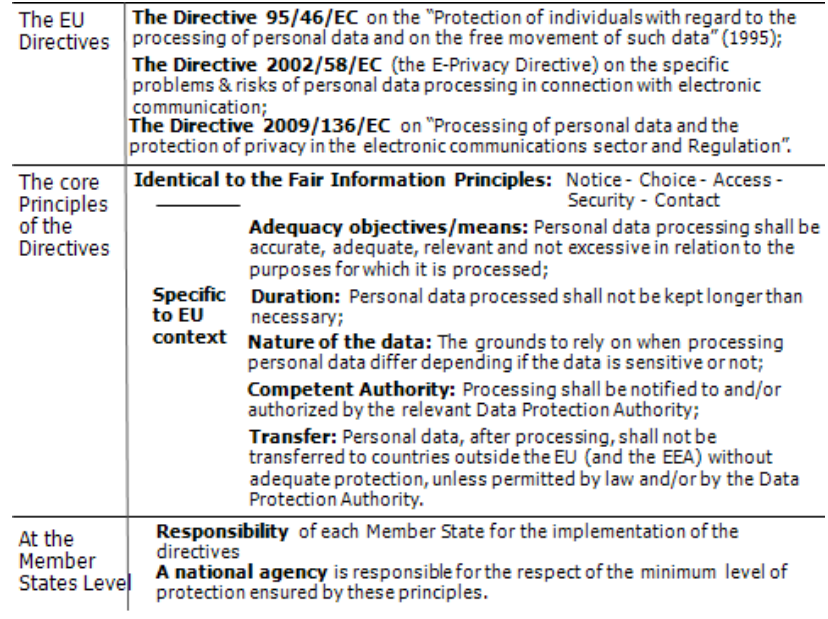

\section{Figure 4. Personal data protection in Europe}

The institutionalisation in each MS is ensured by the establishment of a data protection commissioner, assigned to a ministry or agency that implements at national level the set of regulations and principles (Strauss and Rogerson, 2002; KWR Gmbh, 2006).

In the UK, the Data Protection Act (1998) implements the Directive 95/46/EC. It has been amended in by the Freedom of Information Act (2000) to give a right of access to personal data held by public authority, subject to exemptions (KWR Gmbh, 2006). Other legislation is relevant to the use of personal data, as shown in Figure 5.

\begin{tabular}{|c|c|}
\hline \multirow{5}{*}{$\begin{array}{l}\text { The } \\
\text { United- } \\
\text { Kingdom }\end{array}$} & $\begin{array}{l}\text { The Data Protection Act (1998) } \\
\text { implements the Directive } 95 / 46 / E C\end{array}$ \\
\hline & The Human Rights Act (1998) \\
\hline & $\begin{array}{l}\text { The Freedom Protection Act } \\
(2000)\end{array}$ \\
\hline & $\begin{array}{l}\text { The Regulation of Investigatory Powers } \\
\text { Act }(\mathbf{2 0 0 0 )} \\
\text { about personal data used in } \\
\text { telecommunications }\end{array}$ \\
\hline & $\begin{array}{l}\text { The Privacy and Electronic } \\
\text { Communication (EU Directive) Regulation } \\
\text { (2003) } \\
\text { has provisions dealing with monitoring } \\
\text { telecommunications such as the use of Internet }\end{array}$ \\
\hline
\end{tabular}

Figure 5. Personal data protection in the United-Kingdom

The recent revision of the e-privacy Directive and the current revision of the Directive 95/46/EC shed light on the difficulties to address the stakes related to technology pervasiveness and daily privacy concerns. Additionally, it addresses the difficulties to express privacy resonating the specificity of emerging Internet applications, and social networks, in particular (Poullet, 2010).

\section{Beyond personal data: two tales in the news media}

The two cases chosen to illustrate our research are strongly related with inter-personal communication supported by social networks. These are the so called, Weinergate (e.g. Klein, 2011; Pershing, 2011) and 
the Pudick case (e.g. Blake, 2011a; Davies, 2011). We consider that these two cases have raised privacy issues with regard to the Westin's conception of privacy presented earlier.

The stories in these cases are being looked at from the point of view of the news media narratives, i.e. what the media echo and comment. The cases were heavily reported in the news media, commented in the blogosphere and the kinds of reactions that those stories provoked in the media and in the public ultimately resonate the ways in which technology, in particular "social networks" are raising awareness of how ethical and moral values that once were taken for granted became now moot questions, e.g. privacy (Walther, 2011), reputation (Solove, 2007), etc.

Through these cases we are looking at the narratives about privacy and ethics as portrayed by the news media embracing van Dijk's idea that "the construction of news is most of all a reconstruction of available discourses" (van Dijk, 1983, p. 28).

The 2 case studies have been picked up from the European (UK) and USA contexts. In order to determine how the media has treated them, we selected three national (on-line versions) newspapers: The Independent, The Guardian, The Financial Times for the United-Kingdom and The New York Times, The International Herald Tribune and the Washington Post for the USA. We collected news using keyword search in the newspapers sites. The public commentary to the news articles has also been scrutinised.

\section{Weinergate}

Anthony Weiner is a former U.S. Democratic Congressman, serving New York's 9th District from 1999 until 2011. On May 2011, the congressman mistakenly published in his public Twitter account a lewd picture of himself. Weiner deleted the picture after some minutes, but it was long enough for a conservative group to discover it and publish it in Andrew Breibart's blog ${ }^{1}$. After several days of denying he had posted the image and saying his account had been "hacked", he admitted to having sent sexually explicit photos and messages to about six women over a three-year period, both before and during his marriage. He denied having met, or having had a physical relationship with any of the women. On June 16, 2011, Weiner announced his resignation from Congress.

\section{THE FRAMING OF THE CASE IN THE MEDIA}

In Weiner's case, the technology potentiated and facilitated diverse steps of the case.

First, Twitter facilitated Weiner's affairs, which decades back would have demanded a different process, longer times, and reflections.

"So where does Anthony Weiner fit in? A generation ago, we couldn't have had a sex scandal based on Facebook messages, tweets and e-mails. That's progress, of a sort." (Klein, 2011).

Second, Weiner's use of Twitter intertwined his personal (private) and professional life. While his Twitter name related to his profession - @RepWeiner, and included links to his campaign website, Weiner was using the technology to carry out personal relationships.

"Like many lawmakers, Weiner tweets a mix of personal and political observations. His Twitter user name @RepWeiner - identifies him as a member of Congress. But his Twitter page links to his campaign Web site, not his official House site" (Pershing, 2011).

Third, Twitter potentiated error. A basic flaw (leaving out a " $\mathrm{d}$ ") transformed a private message in a public one.

1 Andrew Breibart is a conservative blogger, publisher and commentator for the Washington times. 
"Here we see a character flaw meeting a design flaw. The mistake was Weiner's - he hit the wrong key, an "@" instead of a "D," and thus sent the lewd photo to tens of thousands of people instead of one. But a good technology assumes operator error, and has built-in corrections or failsafes. A robust system presumes that dopes will grab the controls" (Achenbach, 2011).

Fourth, Twitter enabled user's activities tracking.

"Conservative group \#BornFreeCrew had for weeks before the "Weinergate" scandal closely monitored who the congressman was following on Twitter, and even urged young women to stay away from him, according to Slate. (...) Dan Wolfe, the man who discovered Weiner's crotch shot and sent it to conservative blogger Andrew Breitbart (...) [had] for weeks promised that a scandal was coming" (Flock, 2011).

Fifth, Twitter facilitated the perverse proliferation of posts about the case, multiplying the number of people looking at his private life (Sargent, 2011a; Petri, 2011).

"I enjoy Twitter as much as the next fellow, but if there's one conclusion you can draw from Weinergate, it's that Twitter - in addition to all its virtues - can encourage and reinforce pack journalism's very worst instincts. The unfolding of Weinergate on Twitter was a deeply dispiriting spectacle. There were times when the wall of puerile and adolescent Tweets about Weiner grew impenetrable. Anyone reporting and Tweeting on any other topic could be assured that it would get entirely lost." (Sargent, 2011b).

"A generation ago, we would've been doing something more productive than looking at Weiner's Facebook posts, tweets and e-mails." (Klein, 2011).

Last, but not least the private pictures were sent to these women in a private context (even though using Twitter), but IT potentiated the exposure of private life with consequent damage for Weiner's reputation.

\section{Puddick "Online Harrassment"}

Ian Puddick, a self-employed plumber from Enfield, north London, UK was accused of "online harassment" after using a variety of social networks and a series of websites to expose his wife's affair with her boss (Mr. Haynes), a director from a leading global reinsurance company. The prosecution claimed that Ian Puddick's actions to expose his wife's affair forced the director to resign from his post. After a three-day trial at the City of Westminster Magistrates' Court, Ian Puddick was cleared of two charges of Internet harassment. This recent case was followed by legal and media experts, since it raised important questions over the limits of online freedom of speech and the regulation of what is disseminated through Internet and, particularly, via social network websites.

The framing of the case in the media

In the Puddick case, social networks were used to damage the reputation, to distress and to shame a man involved in adultery.

First, the media describes a clash between technology and regulation, equating discourses of freedom of speech and Internet regulation.

"The case is being followed by legal and media experts as the battle to regulate what is disseminated through websites and on Twitter is waged in the courts. Recent cases involving injunctions have also raised questions over freedom of speech and the regulation of the internet" (The Guardian, 2011)

"Lawyers believe the three-day hearing could help define the limits of free expression online" (The Independent, 2011)

"The landmark case has renewed interest in the clash of technology and the legal system as information is spread via unregulated social media sites." (Blake, 2011a). 
Second, technology is not deemed protective of all users; reach out and speed at which Internet proliferates information, appropriation of identity, etc. As for the Weinergate case, IT potentiated the exposure of private life with consequent damage for the actors involved.

"Mr. Haynes told the court: 'I think most of the country, thanks to the Internet, is aware I had an affair'." (Blake, 2011a)

"[Mr Haynes] 'embarrassment and shame' after (...) clients were contacted through fake profiles on social networking site LinkedIn." (Idem.)

Third, the media is not concerned with the moral of Mr. Puddick's endeavour to get his wife back. The title of a photo published in Davies (2011) suggests that any purpose justifies the means. In fact Mr. Puddick was cleared from two harassment charges.

"It is absolutely a victory for free speech and the small man. I'm a plumber and drive a Transit." (Davies, 2011).

Finally, the media takes stock of the case inspiring government to take action regarding cyberstalking, as well as well as social networks regulation.

"outdated cyberstalking laws [... this] was prompted by a flurry of recent cases in which stalkers have used texts, tweets, chatrooms and sites such as Facebook to intimidate their victims" (Blake, 2011b).

\section{Discussion: privacy concerns in the two cases}

\section{Making a case for privacy in the two cases}

The media discourses did not use the "privacy" lens in both cases; they seem to be centred on moral aspects, as well as on vulnerabilities of people grappling with the effects of unregulated and un-discussed ethics of social networks.

Westin's (1967) conception of privacy, which distinguishes four functions and states of privacy, interest both cases. In the Weinergate case, privacy was put at jeopardy with Weiner's involuntary misuse of technology: the "reserve state" defined as "the desire to limit disclosures to others" was defied due to mistaken use of Twitter. Twitter is not deemed ergonomically respectful of one's "limitation and protection of communication", one of Westin's privacy functions. In the Puddick case, three of Westin's states of privacy were put at jeopardy when Mr. Puddick published his wife's affair in an attempt to ruin her lover's reputation through social networks: "solitude" - the state of being free from observation by others, anonymity and reserve, "anonymity" - the condition of being unknown and free from identification - and the state of "reserve". We argue that Mr. Puddick's wife and her lover have been deprived from their "personal autonomy" (one of the functions of privacy) since they were "manipulated, dominated and exposed" by him.

One of the outstanding issues in these cases is that neither Mr. Weiner nor Mr. Haynes could control both the disseminated information and subsequent interaction. In Altman's (1975) properties of privacy, this maps on "non-monotonic nature of privacy" and "boundary regulation process" since in both cases the technology caused either involuntary error, or unawareness about publication of one's private facts, or even identity theft. Moreover, as far as units of privacy are concerned we have here a conflict between the person-to-person unit and person-to-group one. In the Puddick case, this arises because he decided to make public a private matter involving three people. In the Weiner case, media news considered naif Weiner's expectations that online private conversations could remain that way.

Yet, narratives of privacy are not used in the relevant media news regarding the two cases; a possible explanation is that current privacy does not contemplate further functions or units of privacy other than those expressed in data protection initiatives. Having said that, we find it interesting that at the light of existing EU regulation the Puddick's court case were not treated as a privacy matter for two reasons. First, if 
someone's identity is falsified or an erroneous public image of his/her personality is conveyed to others, we have a case for identity infringement (Andrade, 2011) - Mr. Puddick had created a false identity in LinkedIn to connect to Mr. Hayne's acquaintances and further defame him. Andrade and other authors argue that privacy is infringed "if true private facts related to a person are revealed to the public". Mr. Puddick was "cleared of harassing his wife's millionaire lover on the Internet" (Davies, 2011); he was absolved on the grounds that he had published true facts about his wife's lover, which therefore made it a case for free speech under UK law.

Second, given that Directive 95/46/EC automatically qualifies any person as a data controller when he/she publishes personal data about others in social networks, Mr. Puddick could have been qualified as such. Hence, all provisions regarding personal data processing could apply. And were the blogger in Mr Weiner case in Europe, the same reasoning could apply.

Even if the media accounts of those two cases were not framed in privacy narratives, we would argue that they are strongly framed in privacy issues, and at least the Puddick case could have been already addressed through existing regulation. Finally, it should be interesting to investigate why other less articulated ethical framings (e.g. reputation, identity, etc.) did not emerge in the media news. A likely possibility is that our conceptions of privacy are being questioned and are no longer warranted.

\section{Technologies of privacy}

Poullet (2010) illustrated that in order to ensure proper protection of values such as privacy, an alignment of technology and regulation has to be sought. In these two cases the technology did not provide mechanisms to the users to protect their privacy - e.g. providing functionality to give consent to others to publish about oneself and redundancy or "undo" functions. Some could think that the technology is not at stake here, since people should be knowledgeable of its workings, before using it. But we sustain that this type of idea is a shift of burden, since the technology should be conceived from the start to comply with users' expectations of (privacy) self-protection.

Walther (2011) argues that there are three factors that are confronting online users and their expectations: 1) misplaced presumption that online behaviours are private; 2) that the Internet nature is incommensurate with privacy as we know it; and 3) that one's faith that private online "conversations" remain as such. Whether or not we concur with these ideas, technology is not to be taken for granted as far as protection of privacy is concerned; the two cases illustrate that technology did not protect the actors involved. In other words, it did not shield them from involuntary exposure due to either mistaken IT use, or to lack of control of published personal information.

\section{Towards an ethics of social networks}

Scholars of science and technology studies have long demonstrated the co-evolution of technology and society (e.g. Latour, 1992; Jouët, 1993; Jasanoff, 1995). Feenberg (2010) articulates this as a democratic paradox: "the public is constituted by the technologies that bind it together but in turn it transforms the technologies that constitute it". With this realization, von Schomberg (2007) argues that the classical ethical theory and the conventional ethical practice do not address both aspects of unintentional side consequences and collective decisions that should be taken into account while considering the issues of ethical responsibility in scientific and technological developments. Hence, as with many emergent technologies, we are left with old narratives, meanings and rules to deal with quite different phenomena and their anticipated and unintended effects.

There are some initiatives attempting to deal with current critique of technology contempt of ethical and societal concerns. For example, in the EU, proposals for developing technology embodying "ethics by design" or "privacy by design" paradigms (European Commission, 2010, p. 12), or proposals for placing changes in regulation that currently implement traditional ethical concerns, such as Poullet's (2010) ideas of Internet as virtual dwelling. Von Schomberg (2007) proposes an ethic of co-responsibility, that should arise 
from reflection on the social processes in which technological decision making is embedded and which presupposed the following four requirements: public debate; technology assessment; constitutional change; and foresight and knowledge assessment.

Therefore, we reckon we need a deeper interrogation of the current meanings of privacy and other ethics, how they map onto the information and communication narratives, their function in society as well as their stakes. Thorough discussions on ethics of IT and in particular of social networks need to be urgently set.

\section{References}

Achenbach, J. (2011). "Anthony Weiner: Character flaw meets design flaw". The Washington Post Blogs, available at: http://www. washingtonpost.com/blogs/achenblog/post/anthony-weiner-character-flawmeets-design-flaw/2011/06/09/AGZci8MH_blog.html. Published: June 9.

Altman, I. (1975). The environment and social behavior: privacy, personal space, territory, and crowding. Monterey, Brooks/Cole Publishing Company.

Andrade, N.N.G.d. (2011). "Data Protection, Privacy and Identity: Distinguishing Concepts and Articulating Rights". Privacy and Identity Management for Life - IFIP Advances in Information and Communication Technology, 352: 90-107.

Blake, M. (2011a). "'Online harassment' over affair leads to landmark court case". The Independent, available at: http://www.independent.co.uk/news/uk/home-news/online-harassment-over-affair-leads-tolandmark-court-case-2298064.html. Published: June 16.

Blake, M. (2011b). "Government to launch inquiry into 'outdated' cyberstalking laws". The Independent, available at: http://www.independent.co.uk/news/uk/crime/government-to-launch-inquiry-intooutdated-cyberstalking-laws-2299286.html. Published: June 18.

Carew, P. J. and L. Stapleton (2005). Towards a Privacy Framework for Information Systems Development. Information Systems Development: Advances in Theory, Practice and Education. O. Vaselicas, A. Caplinskas, W. Wojtowskiet al. New York, Springer Science + Business Media: 77-88.

Davies, C. (2011). "Plumber Ian Puddick cleared of harassing wife's lover on internet". The Guardian, available at: http://www.guardian.co.uk/uk/2011/jun/17/ian-puddick-internet-cleared-twitter. Published: June 17.

DeCew, J. (2008). "Privacy" The Stanford Encyclopedia of Philosophy, available at: http://plato.stanford.edu/archives/fall2008/entries/privacy/.

De Hert, P. and Gutwirth, S. (2006). Privacy, data protection and law enforcement. Opacity of the individual and transparency of power. In Privacy and the criminal law. E. Claes, A. Duff and S. Gutwirth. Antwerp/Oxford, Intersentia: 61-104.

European Commission. (2010). "A comprehensive approach on personal data protection in the European Union". Communication from the Commission to the European Parliament, the Council, the Economic and Social Committee and the Committee of the Regions, COM(2010) 609 final. Available at: http://ec.europa.eu/justice/news/consulting_public/0006/com_2010_609_en.pdf.

Feenberg, A. (2010). "Ten paradoxes of Technology." Techné 14(1): 3-15.

Flock, E. (2011). "\#BornFreeCrew: The group who warned about Weiner". The Washington Post, available at: http://www. washingtonpost.com/blogs/blogpost/post/bornfreecrew-the-group-who-warned-aboutweiner/2011/06/20/AGE8L2CH_blog.html. Published June 21.

Jasanoff, S. (1995). Science at the Bar: Law, Science, and Technology in America, a Twentieth Century Fund book. Cambridge, MA: Harvard University Press.

Joinson, A. N. and Paine, C. B. (2007). Self-disclosure, privacy and the Internet. In The Oxford Handbook of Internet Psychology A. N. Joinson, K. McKenna, T. Postmes and U.-D. Reips. New York, Oxford University Press: 237-252.

Jouët, J. (1993). « Pratiques de communication et figures de la médiation ». Réseaux, 11/60, 99-120.

Klein, E. (2011). "A techno-history of Congress". The Washington Post Blogs, available at: http://wWw. washingtonpost.com/business/economy/a-techno-history-ofcongress/2011/06/13/AGwLB/TH_story.html. Published: June 14. 
KWR Gmbh. (2006). Data Protection in the European Union and other Selected Countries: A New Comparative Study. http://www.kwr.at/fileadmin/res/pdf/publikationen/mag-arnocichocki/10541_Data_Protection_Austria.pdf [October, 20th, 2011]

Kuczerawy, A. (2010). "Facebook and Its EU Users - Applicability of the EU Data Protection Law to US Based SNS*". M. Bezzi et al. (Eds.): Privacy and Identity, IFIP AICT 320: 75-85.

Latour, B. (1992). "Where are the Missing Masses? The Sociology of a Few Mundane Artifacts", in: Shaping Technology/Building Society: Studies in Sociotechnical Change, Bijker, W.E. and Law, J. (Eds), MIT Press, USA, pp. 225-258.

Margulis, S. T. (2011). Three Theories of Privacy: An Overview. Privacy Online, Perspectives on Privacy and Self-Disclosure in the Social Web. S. Trepte and L. Reinecke. Berlin, Heidelberg, Springer-Verlag: 9-17.

Pedersen, D. M. (1999). "Models for types of privacy by privacy functions." Journal of Environmental Psychology 19(4): 397-405.

Pershing, B. (2011). "A Weiner ethics case would cover uncharted ground". The Washington Post, available at: http://www.washingtonpost.com/politics/a-weiner-ethics-trial-would-cover-unchartedground/2011/06/09/AGbG6dNH_story.html. Published: June 9.

Petri, A. (2011). "The hypocritical Weiner furor and the Laws of the Internet". The Washington Post Blogs, available at: http://www. washingtonpost.com/blogs/compost/post/the-hypocritical-weiner-furor-andthe-laws-of-the-internet/2011/03/03/AG4WUbXH_blog.html. Published: June 16.

Poullet, Y. (2010). About the E-Privacy Directive: Towards a Third Generation of Data Protection Legislation? Data Protection in a Profiled World. S. Gutwirth, Y. Poullet, P. De Hert, Springer Netherlands: 330.

Sargent, G. (2011a). "Weiner resigns, and Twitter claims its first major political casualty". The Washington Post Blogs, available at: http://www.washingtonpost.com/blogs/plum-line/post/weiner-resigns-andtwitter-claims-its-first-major-political-casualty/2011/03/03/AGXZRNXH_blog.html. Published: June 16.

Sargent, G. (2011b). "Please, no more media 'Twittergasms'". The Washington Post Blogs, available at: http://www.washingtonpost.com/blogs/plum-line/post/please-no-more-mediatwittergasms/2011/03/03/AGOux3cH_blog.html. Published: June 20.

Solove, D.J. (2007). The Future of Reputation: Gossip, Rumor, and Privacy on the Internet. Yale University Press, New Haven and London.

Strauss, J., and Rogerson K. S. (2002). "Policies for online privacy in the United States and the European Union". Telematics and Informatics 19 (2002) 173-192.

The Guardian (2011). "Man on trial over Twitter 'affair' claims says case has 'big legal implications'". The Guardian, available at: http://www.guardian.co.uk/technology/2011/jun/15/twitter-affair-claims-legalimplications. Published: June 15.

The Independent (2011). "'Shame' of affair boss outed online". The Independent, available at: http://www.independent.co.uk/news/uk/crime/shame-of-affair-boss-outed-online-2297652.html. Published: June 15.

van Dijk, T. A. (1983). "Discourse Analysis: Its Development and Application to the Structure of News". Journal of Communication Spring 1983 Volume 33:2 20-43.

von Schomberg, $R$. (2007). From the ethics of technology towards an ethics of knowledge policy/knowledge assessment - Working Document. Publication series of the Governance and Ethics unit of DG Research. Brussels, European Commission.

Walther, J. B. (2011). Introduction to Privacy Online. Privacy Online: Perspectives on Privacy and Selfdisclosure in the Social Web. S. Trepte and L. Reinecke. Heidelberg, Springer: 3-8.

Westin, A. (1967). Privacy and Freedom. New York, Atheneum. 